\title{
Procoagulant inhibitory properties of paclitaxel poliglumex
}

This article was published in the following Dove Press journal:

International Journal of General Medicine

14 December 2010

Number of times this article has been viewed

\author{
John Nemunaitis ${ }^{1,2,3}$ \\ Neil Senzer ${ }^{1,2,3}$ \\ Barry Cooper ${ }^{2,3}$ \\ Michael Nemunaitis' \\ Cynthia Bedell' \\ Jack W Singer ${ }^{4}$ \\ Fred B Oldham ${ }^{4}$ \\ 'Mary Crowley Cancer Research \\ Centers, Dallas, TX, USA; ${ }^{2}$ Baylor \\ Sammons Cancer Center, Dallas, TX, \\ USA; ${ }^{3}$ Texas Oncology, Dallas, \\ TX, USA; ${ }^{4}$ Cell Therapeutics, Inc., \\ Seattle, WA, USA
}

Background: In Phase I evaluation of CT-2103 (paclitaxel poliglumex), prolongation of prothrombin time (PT) and activated thromboplastin time (aPTT) was observed, without clinical consequence, with doses 1.3-1.5 times higher than the current clinical dose of $175 \mathrm{mg} / \mathrm{m}^{2}$. This Phase I, open-label, nonrandomized pilot study was performed to study the effect of the standard dose regimen on blood coagulation.

Methods: Seven previously treated solid tumor patients received CT-2103 $175 \mathrm{mg} / \mathrm{m}^{2}$ intravenously on day 1 of 21-day cycles for a mean of 5.4 cycles (median 4, range 2-14). Plasma samples were collected for cycle 1 predose and at hours 1, 24, 48, and 72 after the end of administration for drug levels, and for PT and aPTT assays.

Results: No coagulopathy-related adverse events were documented. Bleeding time remained normal in the six patients tested, with transient increases in PT and aPTT noted but resolving within 72 hours. Titration studies at $100 \mu \mathrm{g} / \mathrm{mL}$ of CT-2103 (corresponding to the standard clinical dose) prolonged PT and aPTT clotting times, produced a modest dose-dependent reduction of thrombin and factor Xa, and no significant changes in factors IXa, XIa, or XIIa. Two patients achieved stable disease for $\geq 10$ cycles.

Conclusion: CT-2103 is associated with transient prolongation of PT and aPTT without clinical sequelae.

Keywords: CT-2103, paclitaxel, poliglumex, cancer

\section{Introduction}

CT-2103 (paclitaxel poliglumex), the ester conjugate of $\alpha$-poly-L-glutamic acid and paclitaxel linked through a $2^{\prime}$ hydroxyl site, ${ }^{1-3}$ is an investigational agent under development for the treatment of human cancer. ${ }^{4-10}$ The bioactive moiety, paclitaxel, is released from the polymeric backbone primarily in tumor tissue after uptake and proteolytic hydrolytic degradation of the compound. CT-2103 shares structural similarities (ie, a large polyanionic molecule) with heparin.

In an initial Phase I clinical trial, prolongation of prothrombin time (PT) and activated partial thromboplastin time (aPTT) was observed in patients given doses 1.3-1.5 times higher than the current clinical dose of $175 \mathrm{mg} / \mathrm{m}^{2}{ }^{11}$ This effect was dose-dependent, and PT and aPTT clotting times returned to baseline within 48 hours. The time frame was consistent with the mean peak plasma drug concentration $\left(\mathrm{C}_{\max }\right)$ during the first 48 hours. However, bleeding complications were not seen in patients receiving CT-2103. The correlation, if any, between CT-2103 administration and prolongation of PT and aPTT clotting times was therefore unclear.
Correspondence: John Nemunaitis I700 Pacific Ave., Suite I 100, Dallas, TX 7520I, USA

Tel + I 2146581964

Fax +I 2146581992

Email jnemunaitis@marycrowley.org submit your manuscript | www.dovepress.com

Dovepress

DOI: $10.2147 / 1 \mathrm{JGM} . \mathrm{S} 12170$
International Journal of General Medicine 201 I:4 5-II

(C) 20 I I Nemunaitis et al, publisher and licensee Dove Medical Press Ltd. This is an Open Access article which permits unrestricted noncommercial use, provided the original work is properly cited. 
The procoagulant inhibitory effect of CT-2103 in human blood $^{12,13}$ was subsequently studied in ex vivo and in vitro studies, using a dose range based on the plasma $\mathrm{C}_{\max }$ in patients who had received CT-2103 at doses up to $225 \mathrm{mg} / \mathrm{m}^{2}$. These Phase 1 studies confirmed a dose-dependent prolongation of PT and aPTT values, but did not show a significant inhibition of these effects with the addition of protamine sulfate or epichlorohydrin triethanolamine cellulose, two agents known to inhibit the "heparin-like" effect of the assays. Addition of normal plasma partially corrected the prolonged PT and aPTT values, suggesting an inhibitor effect, and a reduction in aPTT times was not observed upon addition of platelet phospholipids and hexagonal phase phospholipids, arguing against a "lupus anticoagulant" effect. The current pilot study therefore sought to investigate the mechanism for prolonged PT and aPTT times further in patients treated with CT-2103.

\section{Materials and methods Study objectives}

The purpose of the study was to determine whether standarddose single-agent CT-2103 affected blood coagulability when administered to patients with solid tumors. Specific study objectives were: to determine the effect of CT-2103 over a range of therapeutically relevant concentrations on PT and aPTT measurements in ex vivo coagulation with normal human blood; to examine the effect of replacing heparin with therapeutically relevant concentrations of CT-2103 in in vitro assays of heparin/antithrombin III (AT-III) inhibition of thrombin and factor Xa enzyme activity; and to assess the effect of CT-2103 on in vitro enzyme activity assays of thrombin and factors Xa, IXa, XIa, and XIIa.

\section{Design}

This was an open-label, nonrandomized, single-center Phase I study of CT-2103 $175 \mathrm{mg} / \mathrm{m}^{2}$ given intravenously (IV) on day 1 of 21-day cycles in patients with advanced solid tumors. Patients were treated until unacceptable toxicity, disease progression, or a complete response occurred, and patients demonstrating a complete response were permitted to receive a maximum of two additional cycles of study medication.

Eligible patients were those who had either failed first-line therapy or had a tumor for which no first-line therapy was available and were felt to be appropriate for treatment with a single-agent taxane. Additional eligibility requirements were aged 18-80 years, Eastern Cooperative Oncology Group performance status 0 or 1, adequate hematologic function (hemoglobin $\geq 9 \mathrm{~g} / \mathrm{dL}$, absolute neutrophil count $\geq 1.2 \times 10^{9} / \mathrm{L}$, platelet count $\geq 100 \times 10^{9} / \mathrm{L}$ ), adequate renal function with serum creatinine $<1.25 \times$ upper limit of normal range [ULN], and adequate hepatic function [total bilirubin $\leq 1.25 \times \mathrm{ULN}$ and aspartate transaminase, alanine transaminase, and alkaline phosphatase $\leq 2.5 \times \mathrm{ULN}]$ ). If liver metastases were present, aspartate transaminase and alanine transaminase had to be $\leq 5 \times \mathrm{ULN}$, and higher alkaline phosphatase levels were permitted with laboratory documentation demonstrating bone origin (ie, bone metastases). Women of reproductive potential were required to have a negative pregnancy test prior to study entry, and all patients had to sign an institutional review board-approved informed consent form indicating they were aware of the investigational nature and known risks of the study.

Exclusion criteria included patient or family history of hemorrhagic diathesis, recent history of thrombosis or prior coagulopathy, and peripheral neuropathy $>$ Grade 1 . Patients could not be on anticoagulant or antiplatelet adhesive therapy, including anticoagulants for venous access maintenance, and prior treatment for cancer was prohibited within three weeks of the first study treatment.

Laboratory and clinical evaluations (eg, physical examination, Eastern Cooperative Oncology Group performance status) were done at baseline, during treatment, and at the end of treatment visits. Tumor response was assessed in the third week of every even-numbered treatment cycle. Toxicities were assessed according to the National Cancer Institute Common Terminology Criteria for Adverse Events, Version 3, at each patient visit.

Blood samples to evaluate plasma drug levels and coagulation parameters were collected into Vacutainer tubes containing sodium heparin during cycle 1 at predose and again at hours 1, 24, 48, and 72 after the end of the first CT-2103 administration. Blood samples were collected from the arm contralateral to the site used for the CT-2103 infusion. After collection, the blood samples were placed in an ice bath and then centrifuged at $2000 \mathrm{rpm}$ for 15 minutes at $4^{\circ} \mathrm{C}$ to separate plasma. Plasma was transferred into polypropylene screwcap vials and stored in a freezer set to maintain a temperature of $-60^{\circ} \mathrm{C}$ to $70^{\circ} \mathrm{C}$ until analysis.

If PT and/or aPTT levels were elevated at the 72-hour evaluation, additional PT and aPTT assessments were done every 3-5 days until levels returned to normal.

\section{Drug reconstitution and dilution}

Before administration, CT-2103 was reconstituted to a solution at a strength of $90 \mathrm{mg} / 10 \mathrm{~mL}$ by rapidly injecting $9.8 \mathrm{~mL}$ 
sterile water for injection into the vial. The required volume of reconstituted drug product (to produce the required dose per square meter of body surface area) was transferred to a low-adsorption non-PVC plastic IV bag containing $100 \mathrm{~mL}$ of $5 \%$ dextrose injection in water (D5W). A volume of diluent equivalent to the volume of reconstituted drug solution was not withdrawn from the IV bag; the entire volume of $100 \mathrm{~mL}$ D5W was used. The diluted drug product was administered with a pump as a 10-minute infusion into a peripheral vein or central line using a low-adsorption non-PVC administration set, without an inline filter.

\section{Bleeding and coagulation assays}

The CT-2103 concentrations used in these in vitro and ex vivo coagulation studies were determined from human clinical pharmacokinetic data obtained in four prior Phase I doseescalation studies with one-, two-, and three-week schedules (Table 1). Results revealed a biphasic decline in CT-2103 concentration, with a distribution phase of approximately 48 hours followed by a longer terminal phase associated with drug elimination. Bleeding time was performed by the traditional Ivy method. ${ }^{14}$

\section{PT and aPTT assays}

A series of samples containing $898 \mu \mathrm{L}$ pooled normal plasma (Haematologic Technologies, Inc., Essex Junction, VT) and $102 \mu \mathrm{L}$ of CT-2103 in $50 \mathrm{mM}$ Tris, $0.175 \mathrm{M} \mathrm{NaCl}, 7.5 \mathrm{mM}$ EDTA pH 8.4 (assay buffer) yielding 0, 50, 100, 150, 200, 250 or $300 \mu \mathrm{g}$ paclitaxel equivalents $/ \mathrm{mL}$ were prepared in microcentrifuge tubes. The tubes were mixed by inversion and placed on ice. Next, $100 \mu \mathrm{L}$ of each sample was added to each well of an MLA Electra 700 coagulation timer cuvette, and the aPTT and PT assays were initiated on an MLA

Table I Time to peak plasma concentration of conjugated taxane with various CT-2103 doses

\begin{tabular}{llll}
\hline $\begin{array}{l}\text { Study } \\
\text { number }\end{array}$ & $\mathbf{n}$ & Dose $\left(\mathrm{mg} / \mathrm{m}^{2}\right)$ & $\begin{array}{l}\mathrm{C}_{\max }(\mu \mathrm{g} / \mathrm{mL}), \text { mean } \\
\text { and SD }\end{array}$ \\
\hline $1052 \mathrm{a}$ & 6 & 233 & $117.7 \pm 21.2$ \\
& 6 & 266 & $173.0 \pm 79.2$ \\
$1052 \mathrm{~b}$ & 6 & 177 & $77.5 \pm 24.4$ \\
& 3 & 210 & $105.1 \pm 8.6$ \\
101 & 2 & 235 & $98.7 \pm 17.5$ \\
& 3 & 270 & $146.0 \pm 17.3$ \\
102 & 5 & 20 & $11.6 \pm 2.5$ \\
& 4 & 40 & $18.1 \pm 1.3$ \\
105 & 6 & 235 & $131.0 \pm 45.9$ \\
& 6 & 270 & $158.2 \pm 25.6$ \\
\hline
\end{tabular}

Abbreviations: $S D$, standard deviation; $C_{\max }$, time to peak plasma concentration.
Electra 700 coagulation timer which dispensed $200 \mu \mathrm{L}$ per well of PT reagent (Hemoliance RecombiPlasTin; Instrument Laboratories, Lexington, MA) for the PT test or $100 \mu \mathrm{L}$ per well of Auto aPTT (BioMerieux, Durham, NC) and $100 \mu \mathrm{L}$ per well $25 \mathrm{mM} \mathrm{CaCl}_{2}$ (JT Baker, Phillipsburg, NJ) with a 300 -second incubation time for the aPTT assay. Data were represented in a plot of $\mu \mathrm{g}$ paclitaxel-equivalents $/ \mathrm{mL}$ versus PT and aPTT clot times in seconds.

\section{Heparin/AT-III assays for inhibition of $\alpha$-thrombin and factor Xa}

A series of heparin standards was prepared by adding 0-1.0 U/ $\mathrm{mL}$ heparin sodium (Porcine Elkin-Sinn, Inc., Cherry Hill, NJ) to microcentrifuge tubes and diluting up to final volumes of $900 \mu \mathrm{L}$ with $50 \mathrm{mM}$ Tris, $0.175 \mathrm{M} \mathrm{NaCl}, 7.5 \mathrm{mM}$ EDTA pH 8.4 (assay buffer). A series of CT-2103 dilutions was prepared by adding various quantities to a microcentrifuge tube and diluting up to $900 \mu \mathrm{L}$ with assay buffer, then $100 \mu \mathrm{L}$ of a $350 \mu \mathrm{g} / \mathrm{mL}$ solution of human AT-III (Haematologic Technologies, Inc.) was added to the heparin-standard and CT-2103 tubes. A negative control was also included by adding only the $300 \mu \mathrm{g}$ paclitaxel-equivalents $/ \mathrm{mL}$ volume to a microcentrifuge tube, bringing the volume up to $1000 \mu \mathrm{L}$ with assay buffer (no AT-III). All tubes were mixed by inversion. Next, $100 \mu \mathrm{L}$ of each sample or standard was transferred to a medium binding plate (CoStar, Bethseda, MD) and the plate incubated at $37^{\circ} \mathrm{C}$ for four minutes. Following incubation, $50 \mu \mathrm{L} /$ well of $6 \mathrm{NIH} \mathrm{U} / \mathrm{mL}$ human $\alpha$-thrombin or $50 \mu \mathrm{L} /$ well of $12 \mathrm{U} / \mathrm{mL}$ human factor Xa (Haematologic Technologies, Inc.) was added for the respective tests, and the plate incubated again at $37^{\circ} \mathrm{C}$ for exactly 30 seconds. Next, $100 \mu \mathrm{L}$ of $1 \mathrm{mM}$ Spectrozyme TH or Spectrozyme Xa (American Diagnostica, Stamford, CT) was added to each well of the plate and beginning immediately, the change in absorbance $\left(\Delta \mathrm{A}_{405} / \mathrm{min}\right)$ was monitored for five minutes in a Versa Max plate spectrophotometer (Molecular Devices, Sunnyvale, CA). A standard curve was generated by plotting the heparin concentration (units/mL; abscissa) versus the $\Delta \mathrm{A}_{405} / \mathrm{min}$ (ordinate). CT-2103 inhibition was expressed in terms of heparin units per milligram of CT-2103.

\section{Factor IXa inhibition assay}

First, $220 \mu \mathrm{L}$ of $15 \mu \mathrm{M}$ human factor IXa in $50 \mathrm{mM}$ Tris, $100 \mathrm{mM} \mathrm{NaCl} \mathrm{pH} 7.4$ plus 33\% (v/v) ethylene glycol with and without $100 \mu \mathrm{g}$ paclitaxel-equivalents/mL was added to selected wells of a medium binding assay plate (CoStar). After a brief incubation, $25 \mu \mathrm{L}$ of $10 \mathrm{mM}$ Spectrozyme 
IXa (American Diagnostica) was added and, beginning immediately, $\Delta \mathrm{A}_{405} / \mathrm{min}$ was monitored for five minutes in a Versa Max plate spectrophotometer. Results were expected to be quantitative, indicating whether the addition of CT-2103 caused direct inhibition of factor IXa.

\section{Factor Xla and factor XIla inhibition assays}

One hundred microliters of $1.0 \mu \mathrm{g} / \mathrm{mL}$ human factor XIa (Hematologic Technologies) with or without $100 \mu \mathrm{g}$ paclitaxel equivalents $/ \mathrm{mL}$ in assay buffer was added to selected wells of a medium binding assay plate (CoStar). Following incubation at $37^{\circ} \mathrm{C}$ for four minutes, $100 \mu \mathrm{L}$ of $400 \mu \mathrm{M}$ Spectrozyme XIa (Chromogenix, Milano, Italy) or $100 \mu \mathrm{L}$ of $200 \mu \mathrm{M}$ Spectrozyme XIIa (American Diagnostica) was added as appropriate for the respective tests, and beginning immediately $\Delta \mathrm{A}_{405} / \mathrm{min}$ was monitored for five minutes in a Versa Max plate spectrophotometer. Results were expected to be quantitative, indicating whether the addition of CT-2103 caused direct inhibition of factor XIa or factor XIIa.

\section{Results}

Seven patients were enrolled in the study from February 2002 through to December 2003. As shown in Table 2, patients had been heavily pretreated prior to study enrollment. All but one patient had undergone surgical resection, and three of seven had received radiation therapy.

Table 2 Baseline patient characteristics

\begin{tabular}{|c|c|c|}
\hline \multirow[t]{2}{*}{ Age } & mean & 62.9 \\
\hline & median (range) & $64(5 I-77)$ \\
\hline \multirow[t]{2}{*}{ Gender, n (\%) } & male & I (I4\%) \\
\hline & female & $6(86 \%)$ \\
\hline \multirow[t]{2}{*}{ Baseline ECOG PS - n (\%) } & 0 & $2(29 \%)$ \\
\hline & I & 5 (7I\%) \\
\hline \multirow[t]{2}{*}{ Months since diagnosis } & mean & 51.3 \\
\hline & median (range) & $49.6(14-97)$ \\
\hline \multirow[t]{2}{*}{ Disease stage, n (\%) } & IIIC & I (I4\%) \\
\hline & IV & $6(86 \%)$ \\
\hline \multirow[t]{5}{*}{ Tumor types } & ovarian & $3(43 \%)$ \\
\hline & NSCLC & I (14\%) \\
\hline & primary peritoneal & I (I4\%) \\
\hline & small cell lung & I (I4\%) \\
\hline & endometrial & I (I4\%) \\
\hline \multirow[t]{4}{*}{ Prior treatment regimens } & 3 & I (14\%) \\
\hline & 4 & I (I4\%) \\
\hline & 5 & $4(57 \%)$ \\
\hline & 9 & I (I4\%) \\
\hline
\end{tabular}

Abbreviations: NSCLC, nonsmall cell lung cancer; ECOG, Eastern Cooperative Oncology Group.
All patients experienced at least one adverse event, but most adverse events were $\leq$ Grade 2 . Grade 3/4 adverse events included one instance each of leukopenia (Grade 3), neutropenia (Grade 4), and gamma-glutamyl transpeptidase increase (Grade 3). The only serious adverse event was a Grade 2 occurrence of intestinal obstruction in a patient with primary peritoneal cancer, but this was not considered related to the study medication.

The mean number of cycles delivered was 5.4 (median 4 , range 2-14). At the first efficacy assessment after cycle 2 , three patients were found to have progressive disease and discontinued study treatment. Two of the four remaining patients had progression by cycle 4 , and two patients continued with stable disease through cycle 10 . One patient ended the study with stable disease at cycle 10, and one patient maintained stable disease for over a year until progression was found on the post-cycle 14 assessment.

Bleeding time was evaluated pre- and post-CT-2103 administration in six subjects and remained within normal limits, with only minimal intrapatient variation.

A linear regression analysis of CT-2103 in the Phase I dose-escalation studies versus the experimentally determined $\mathrm{C}_{\max }$ values showed that the highest concentration of CT-2103 utilized $(300 \mu \mathrm{g} / \mathrm{mL})$ was approximately 1.5-2.0 $\times$ the $\mathrm{C}_{\max }$ observed at the highest patient dose administered. ${ }^{11}$

\section{PT and aPTT assays}

As described in the methods section, CT-2103 was titrated into pooled normal plasma, with final concentrations ranging from 50 to $300 \mu \mathrm{g} / \mathrm{mL}$; each sample was approximately one part CT-2103 to nine parts plasma. One part of this mix was added to two parts of RecombiPlasTin to initiate the PT and one part Auto aPTT plus one part $\mathrm{CaCl}_{2}$ to initiate the aPTT assay. CT-2103 titration resulted in PT clot times ranging from 18.2 to 91.3 seconds and aPTT clot times of 104.1 to $>311$ seconds, which was the maximum detection level of the instrument (Figure 1). Comparison of the blank to buffer ( 0 ) control times of both PT and aPTT indicated a slight prolongation in the clot times with the addition of assay buffer only in a ratio of 1:10 in plasma.

The $100 \mu \mathrm{g} / \mathrm{mL}$ CT-2103 concentration (corresponding to the typical clinical dose) resulted in a $1.9 \times$ prolongation of the PT clot time and a $6.8 \times$ prolongation of the aPTT clot time, the maximum that could be measured with the instrument. At the maximal concentration of CT-2103, the PT clot time was prolonged $6.5 \times$. Actual patient aPTT values chronologically 


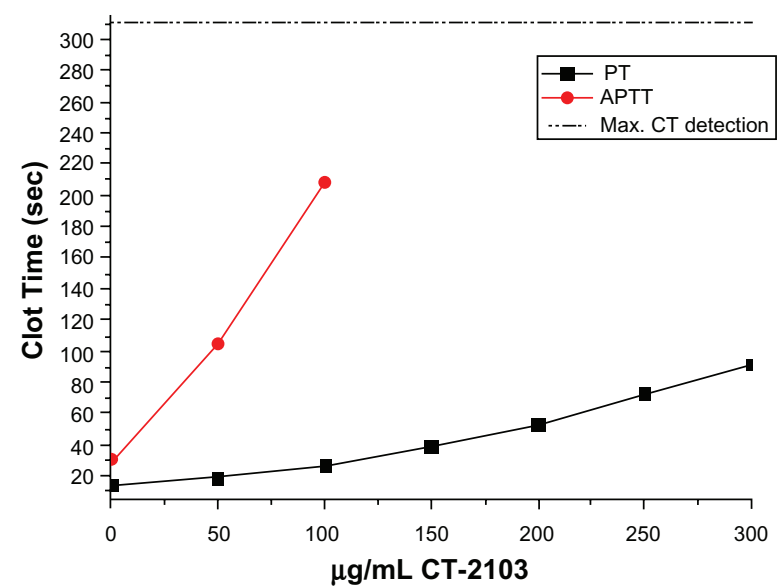

Figure I Prothrombin time (PT) and activated thromboplastin time (aPTT) values versus CT-2103 concentration.

after treatment are shown in Figure 2. A transient increase is shown.

\section{Heparin/AT-III assays for inhibition of thrombin and factor Xa enzyme activity} A standardized heparin preparation was titrated into the assay to achieve final concentrations ranging from 0.125 to $1.0 \mathrm{U} /$ $\mathrm{mL}$, and the inhibition of thrombin and factor Xa enzyme activity by the resulting heparin/AT-III complex were measured using a chromogenic substrate (Figure 3). These data demonstrated a typical dose-response curve of heparin/AT-III complex inhibition of both thrombin and factor Xa activity.

CT-2103 was then titrated into the assay system in place of heparin at a range of final concentrations. Increasing concentrations of CT-2103 in the assay system resulted in a dose-dependent reduction of thrombin (Table 3) and factor Xa

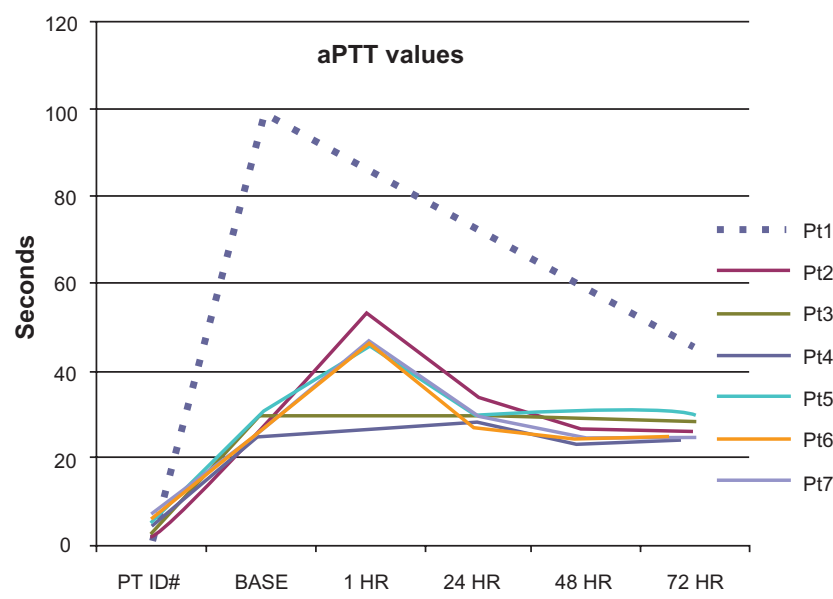

Figure 2 Activated thromboplastin time (aPTT) values over time following CT-2103 administration per patient. Patient identification numbers are shown in the margin.

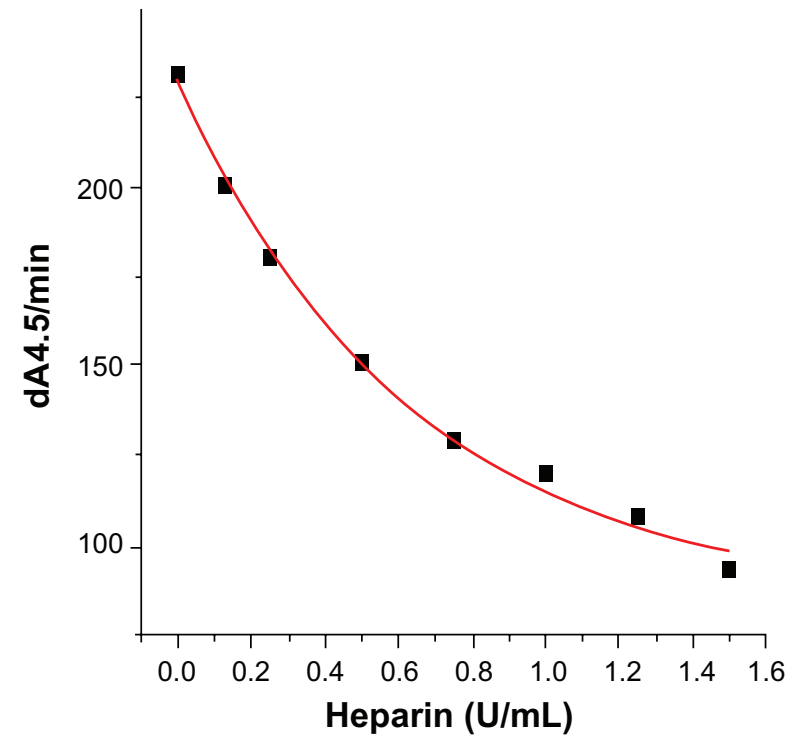

Figure 3 Dose-response curve of heparin/antithrombin III complex inhibition of both thrombin and factor Xa activity.

(Table 4) enzyme activity, expressed as heparin-equivalents $\mathrm{U} / \mathrm{mL}$, from 0.19 to $0.35 \mathrm{U} / \mathrm{mL}$ of heparin.

Table 5 displays control experiments performed with AT-III omitted from the assay, showing that the observed inhibition was independent of AT-III. Collectively, these data indicate that CT-2103 does not express heparin-like activity and confirm that CT-2103 interferes with the ability of thrombin and factor Xa to hydrolyze the chromogenic substrates, Spectrozyme-TH and Spectrozyme-Xa.

\section{Factor IXa, Xla and XIla enzyme inhibition assays}

To investigate the sharp increase in aPTT clot time further, $100 \mu \mathrm{g}$ of CT-2103 was added to chromogenic assays for factors IXa, Xia, and XIIa. These assays (Table 6) showed only a slight decrease in $\Delta \mathrm{A}_{405} / \mathrm{min}$ for factor XIIa and a much greater increase for factor XIa.

Table 3 CT-2103 inhibition of $\alpha$-thrombin activity in heparin assay

\begin{tabular}{llll}
\hline $\begin{array}{l}\text { CT-2 I 03 } \\
\text { dose }(\mu \mathrm{g} / \mathrm{mL})\end{array}$ & $\begin{array}{l}\text { Change in } \\
\text { A405/min }\end{array}$ & $\begin{array}{l}\text { Heparin } \\
\text { equivalent }(\mathrm{U} / \mathrm{mL})\end{array}$ & $\begin{array}{l}\text { Heparin } \\
(\mathrm{U} / \mathrm{mg})\end{array}$ \\
\hline 0 & 245 & 0.04 & - \\
50 & 150 & 0.19 & 3.8 \\
100 & 141 & 0.21 & 2.1 \\
150 & 122 & 0.26 & 1.8 \\
200 & 116 & 0.28 & 1.4 \\
250 & 102 & 0.33 & 1.3 \\
300 & 95.3 & 0.35 & 1.2 \\
\hline
\end{tabular}


Table 4 CT-2103 inhibition of factor Xa activity in heparin assay

\begin{tabular}{llll}
\hline $\begin{array}{l}\text { CT-2 103 } \\
\text { dose }(\mu \mathrm{g} / \mathrm{mL})\end{array}$ & $\begin{array}{l}\text { Change in } \\
\text { A405/min }\end{array}$ & $\begin{array}{l}\text { Heparin } \\
\text { equivalent }(\mathrm{U} / \mathrm{mL})\end{array}$ & $\begin{array}{l}\text { Heparin } \\
(\mathrm{U} / \mathrm{mg})\end{array}$ \\
\hline 0 & 232 & 0.04 & - \\
50 & 214 & 0.06 & 1.2 \\
100 & 193 & 0.15 & 1.5 \\
150 & 176 & 0.27 & 1.8 \\
200 & 166 & 0.36 & 1.8 \\
250 & 162 & 0.40 & 1.6 \\
300 & 152 & 0.52 & 1.7 \\
\hline
\end{tabular}

\section{Discussion}

CT-2103 at a dose of $175 \mathrm{mg} / \mathrm{m}^{2}$ was generally well tolerated in this small study of heavily pretreated advanced cancer patients. No patient achieved a partial or complete response, but two had stable disease for $\geq 10$ cycles. In most patients, the intrapatient time variation of PT was negligible, and no bleeding-related adverse events were reported.

The potential "heparin-like activity" of CT-2103 due to its polyanionic $\alpha$-poly-L-glutamic acid component was tested in assays comparing the inhibition of either thrombin or factor Xa enzyme activity in the presence or absence of AT-III. A modest AT-III-independent inhibition of both thrombin and factor Xa was found, implying that CT-2103 does not possess heparin-like AT-III cofactor activity. The inhibition observed may be the result of a weak but direct inhibition of thrombin and/or factor Xa.

Patients treated with CT-2103 have prolonged aPTT times but do not experience bleeding complications, similar to patients with factor XI or factor XII deficiencies. ${ }^{3-11}$ One plausible explanation for these data, in light of the clinical experience with CT-2103, is that CT-2103 is a serine protease inhibitor with broad specificity and reactivity. Three simple experiments were conducted to determine if CT-2103 directly inhibits factors IXa, XIa, or XIIa. The resulting lack of inhibition of enzyme activity demonstrates that CT-2103 does not directly inhibit these factors.

The similar nature of these experiments, and those conducted with thrombin and factor $\mathrm{Xa}$, suggests that the observed inhibition of thrombin and factor Xa may be the result of a weak but direct inhibition of the enzymes, as

Table 5 Factor Ila and $\mathrm{Xa}$ inhibition is independent of antithrombin III

\begin{tabular}{lll}
\hline Assay & $\begin{array}{l}\text { With AT-III } \\
\text { (change in A405/min) }\end{array}$ & $\begin{array}{l}\text { Without AT-III } \\
\text { (change in A405/min) }\end{array}$ \\
\hline$\alpha$-thrombin & 87.37 & 89.86 \\
Factor Xa & 136.68 & 139.05 \\
\hline
\end{tabular}

Abbreviation: AT-III, antithrombin III.
Table 6 Raw data for factors IXa, Xla, and XII

\begin{tabular}{lll}
\hline $\begin{array}{l}\text { Chromogenic } \\
\text { assay }\end{array}$ & $\begin{array}{l}\text { Enzyme (change } \\
\text { in A405/min) }\end{array}$ & $\begin{array}{l}\text { Enzyme + CT-2 I 03 } \\
\text { (change in A405/min) }\end{array}$ \\
\hline Factor IXa & 138.99 & 148.28 \\
Factor Xla & 68.12 & 111.03 \\
Factor XIla & 221.66 & 186.25 \\
\hline
\end{tabular}

opposed to some form of chemical "interference". However this "interference" did not appear to have a dramatic effect on assays conducted in this study using purified proteins and synthetic substrates. Furthermore, these studies demonstrate that the mechanism does not involve interference with the protein/phospholipid membrane interaction.

Because CT-2103 affects aPTT clotting times, it is conceivable that the mechanism relates to inhibition of the prothrombinase complex (central to both the intrinsic and extrinsic pathways) or to one of the important feedback pathways essential for the propagation phase of blood coagulation. It is important to note that the assays conducted in this study focused on inhibition of procoagulant enzymes, as determined by their ability to hydrolyze small synthetic substrates, and any effect CT-2103 may have on the conversion of zymogens to their respective enzymes remains to be investigated.

\section{Conclusion}

It is proposed that the mechanism of inhibitory activity relates to inhibition of the prothrombinase complex or one of the feedback pathways. CT-2103 presents a new clinical laboratory abnormality for at least 48 hours following dosing which has no observable clinical significance. However, some free paclitaxel ( $<5 \%$ of the paclitaxel dose) undergoes hepatic clearance and inhibits hepatic cytochrome P450. Patients receiving warfarin before or during CT-2103 administration should have continuous monitoring of their international normalized ratio and appropriate and careful modulation of their warfarin dosage.

\section{Disclosure}

FO and JS are employees of Cell Therapeutics, Inc., but final interpretation of the results of this study was made by individuals not employed by Cell Therapeutics, Inc.

\section{References}

1. Matsumura Y, Maeda H. A new concept for macromolecular therapeutics in cancer chemotherapy: Mechanism of tumoritropic accumulation of proteins and the antitumor agent smancs. Cancer Res. 1986;46: $6387-6392$.

2. Greish K, Fang J, Inutsuka T, et al. Macromolecular therapeutics: Advantages and prospects with special emphasis on solid tumour targeting. Clin Pharmacokinet. 2003;42:1089-1105. 
3. Chipman SD, Oldham FB, Pezzoni G, et al. Biological and clinical characterization of paclitaxel poliglumex (PPX, CT-2103), a macromolecular polymer-drug conjugate. Int $J$ Nanomedicine. 2006;1:375-383.

4. Singer JW, Baker B, de Vries P, et al. Poly-(L)-glutamic acid-paclitaxel (CT-2103) [XYOTAX], a biodegradable polymeric drug conjugate: Characterization, preclinical pharmacology, and preliminary clinical data. Adv Exp Med Biol. 2003;519:81-99.

5. Milas L, Mason KA, Hunter N, et al. Poly(L-glutamic acid)-paclitaxel conjugate is a potent enhancer of tumor radiocurability. Int J Radiat Oncol Biol Phys. 2003;55:707-712.

6. Singer JW, Shaffer S, Baker B, et al. Paclitaxel poliglumex (XYOTAX; CT-2103): An intracellularly targeted taxane. Anticancer Drugs. 2005;6 243-254.

7. Singer JW. Paclitaxel poliglumex (XYOTAX, CT-2103): A macromolecular taxane. J Control Release. 2005;109:120-126.

8. Langer CJ. CT-2103. A novel macromolecular taxane with potential advantages compared with conventional taxanes. Clin Lung Cancer. 2004;6 Suppl 2:S85-S88.
9. Boddy AV, Plummer ER, Todd R, et al. A phase I and pharmacokinetic study of paclitaxel poliglumex (XYOTAX), investigating both 3-weekly and 2-weekly schedules. Clin Cancer Res. 2005;11:7834-7840.

10. Sabbatini P, Aghajanian C, Dizon D, et al. Phase II study of CT-2103 in patients with recurrent epithelial ovarian, fallopian tube, or primary peritoneal carcinoma. J Clin Oncol. 2004;22:4523-4531.

11. Nemunaitis J, Cunningham C, Senzer N, et al. Phase I study of CT-2103, a polymer-conjugated paclitaxel, and carboplatin in patients with advanced solid tumors. Cancer Invest. 2005;23:671-676.

12. Adler BK. Unfractionated heparin and other antithrombin mediated anticoagulants. Clin Lab Sci. 2004;17:113-117.

13. Branson HE, Slater LM, Anderson MG, et al. Prothrombin time after heparin removal. Application to monitoring simultaneous anticoagulation with heparin and coumarins. Am J Clin Pathol. 1979;71: 665-667.

14. Beutler E, Lichtman MA, Coller BS, et al, editors. Williams Hematology. 5th ed. New York NY: McGraw-Hill; 1995.
International Journal of General Medicine

\section{Publish your work in this journal}

The International Journal of General Medicine is an international peer-reviewed open-access journal that focuses on general and internal medicine, pathogenesis, epidemiology, diagnosis, monitoring and treatment protocols. The journal is characterized by the rapid reporting of reviews, original research and clinical studies across all disease areas.

\section{Dovepress}

A key focus is the elucidation of disease processes and management protocols resulting in improved outcomes for the patient.The manuscript management system is completely online and includes a very quick and fair peer-review system. Visit http://www.dovepress.com/ testimonials.php to read real quotes from published authors.

Submit your manuscript here: http://www.dovepress.com/international-journal-of-general-medicine-journal 